\title{
The Use of Mobile Phone as Teaching Aid On EFL Students' Speaking Performance and Perception
}

\author{
M. Adieb $\mathrm{H}^{1}$, Johannes A Prayogo ${ }^{1}$, Ekaning Dewanti Laksmi ${ }^{1}$ \\ ${ }^{1}$ Pendidikan Bahasa Inggris-Universitas Negeri Malang
}

\section{INFO ARTIKEL}

\section{Riwayat Artikel:}

Diterima: 21-04-2020

Disetujui: 26-08-2020

\section{Kata kunci:}

mobile phone; speaking performance; students' perception

\author{
Alamat Korespondensi: \\ M Adieb $\mathrm{H}$ \\ Pendidikan Bahasa Inggris \\ Universitas Negeri Malang \\ Jalan Semarang 5 Malang \\ E-mail: m.adieb.h@gmail.com
}

\section{ABSTRAK}

Abstract: This paper presents the effect of Mobile Phone on EFL Students' speaking performance and perception. While mobile phone has been utilized beyond its primary use as a communication tool, there are only a limited number of studies in pedagogy which highlights the importance of mobile phone in teaching-learning activities. The objective of this paper is to show the effect of Mobile Phone as teaching aid on EFL Students' speaking performance and perception. The result of this study shows students who taught using mobile phone outperformed students who taught by conventional teaching.

\begin{abstract}
Abstrak: Penelitian ini berisi tentang pengaruh dari mobile phone terhadap kemampuan bahasa Inggris dan persepsi dari siswa. Banyak kegunaan mobile phone selain sebagai alat komunikasi, namun hanya sedikit yang membahas kegunaan mobile phone di dalam kegiatan belajar mengajar. Penelitian ini bertujuan untuk melihat pengaruh dari mobile phone sebagai bahan bantu pengajaran terhadap kemampuan berbicara siswa. Hasil dari penelitian ini menunjukkan siswa yang belajar dengan menggunakan mobile Phone memiliki pencapain yang lebih baik daripada siswa yang belajar menggunakan cara konvensional.
\end{abstract}

Technology has become an essential mean for human in many aspects; one of them is on teaching. Technology in language teaching has widespread use nowadays. Technology and pedagogy were never much mutual terrains, until today. Both have even been conjoined through the expanding and evolving learning tool establishment. Implementing technology in English as Foreign Language (EFL) classrooms can provide a meaningful and interesting approach for language learning (Andrade, 2014). When we refer terms of technology to education, most people will think about computers and mobile devices-which later give birth to non-computer and computer assisted language learning (Brown, 2015). In the 90s, language laboratories were commonly used by schools to accommodate students to be able to listen to native speakers as model to speak. In $2000 \mathrm{~s}$ computer technology started to integrate in classroom. Presentations in the form of Powe

rPoint displayed with LCD projector are one of the examples that still exist until today. Other portable devices, such as mobile phone and tablets, appear as tools for teaching language. Thus, applications inside handheld devices have become platform for students and teachers to interact in language classroom (Ngaleka \& Uys, 2013).

However, the use of mobile devices in classrooms can either detract or reinforce in learning activities in language classrooms. This can be seen in numerous studies about teacher and student's perception on mobile devices in learning (Gikas \& Grant, 2013, Alamer, 2015, Song, Y. \& Siu, C.K, 2016, Broadbent, 2017). There are certainly some factors which enable mobile phone to detract class activities. Hulme \& Shield (2008) stated that mobile devices being anytime and anywhere is ignored because lesson materials were sent to the learners when they can freely have access to it. Moreover, student did not get the material unless the material sent by the teacher. In addition, mobile phone is also still considered as luxury products, which not everybody can afford.

There are various choices of mobile devices that commonly used by students or teacher for instance mobile phone or computer tablet. Somehow, how the teacher and students use those devices to aid learning activity is more important than choosing devices for learning. In other word, mobile devices are only a tool and the success of learning using it is depending on user of mobile devices itself. 
Nevertheless, some studies revealed positive results of implementing mobile devices based on teacher and students' perspective toward it. Communication through mobile apps such as Email, SMS, Facebook groups, Twitter, and recently WhatsApp become popular in recent decades, and each of these apps has their own characteristics and influences to teaching and learning in inside and outside classroom (Calvo, Arbiol \& Iglesias, 2014). Integration of mobile technologies into learning and teaching gradually increased as educators understand how they use it to support various kinds of learning (Hulme and Shield, 2008).

WhatsApp Messenger mobile app is just one among the most highlighted learning tools which have gained actual recognition from academic communities. It is not only simple, easy and cheap, but it also offers a unique collection of interactive and effective features for language teaching activities, especially in foreign language classes. WhatsApp Messenger is one of messaging apps that offers many kinds of files to share, from picture, audio, video, pdfs, documents, slideshows more easily rather than email or sharing apps (WhatsApp inc, 2017). Moreover, it is a cross-platform mobile application that can be installed on smartphone from Android, iOS, Windows Phone, Symbian and even can be accessed on desktop pc or laptop through WhatsApp Web. With those features, teaching English as foreign language can be more easily done to deliver various kinds of teaching materials.

The use of WhatsApp for teaching learning activity in language classroom also reveals positive results from teacher and students' perspective and its use on teaching learning activity. Using WhatsApp in teaching also brings new platform for teacher to make simple social network in class (Fischer, 2013). With this platform, teaching and discussion between students and teacher can be done outside classroom. Also, WhatsApp bring advantages in technical, educational and academic aspect (Bouhnik \& Deshen, 2014). Implementing WhatsApp in teaching English brings new interaction between teacher and students. Teaching English using WhatsApp Messenger can make classroom borderless as teaching can be done in both in inside and outside classroom. Unfortunately, the use of this app in classrooms has not been widely explored and studies. It is shown that only a few studies on the implementation of WhatsApp Messenger in teaching English conducted. Therefore, this paper was initiated to present a wide perspective of valuing WhatsApp Messenger mobile app as a strategic learning tool in English Foreign Classes.

The problems while using technologies can be technical obstacles for teacher to implement technology in classroom. Vota (2011) pointed out this weakness - teacher competence using technologies - can cause failure in implementing mobile devices technology in classroom. Weinbeger (2011) stated that failure in initiating technology in classroom is stressing the teacher with burden.

Therefore, before implementing mobile devices in classroom, the teacher needs to be educated about how to use the tools. Moreover, encouraging teacher to understand aspects of mobile devices can improve their performance in teaching learning activities. By implementing technology in classroom, people assume that the problem will be overcome.

In fact, a tech-savvy teacher could discover more various teaching contents by utilizing particular supported software or mobile applications developed by education software companies (Goundar, 2011, Gilksmann, 2011). Thus, it does make sense that the spreading technology in form of mobile devices leads to higher demand in accessing learning material through it (Ally, 2009). Considering the promising potentials of implementing technology in classroom, teacher and students are encouraged to involve in the tech-supported learning activities.

\section{METHOD}

The design of this research is quasi-experimental quantitative research with main objective to examine the effect of mobile devices on students' speaking performance and perception. This study involved two groups, experimental groups and control groups. This study used pre-test and post-test to obtain data in form of students' speaking score. There are ten meetings are designed to this study and divided into three steps, one week for pre-test, 8 weeks for treatment and one week for post-test. While in treatment phase, researcher combining conventional teaching and mobile phone technology. Since this research did not get permission to select sample from population, the researcher will select available class which only given two class. One class as experimental group and later as control group.

As mentioned in the previous chapter, the subjects of this study are students from Universitas Muhammmadiyah Malang who attend special class of English for freshmen. This English class consists of four basic skills in English-listening, speaking, reading and writing - and divided into 2 semesters. The students come from non-English departments and the teaching materials are related to their departments. The main investigation in this study is to find the difference the students' speaking achievement taught using mobile phone and printed materials in speaking classroom. The steps of research implementation will be discussed as follows (1) Choose one class as the experimental group and one class as the control group, (2) Giving speaking pre-test to both groups to measure students' speaking prior ability, (3) Giving treatment to the experimental group by teaching speaking using mobile phone interaction, (4) Giving treatment to control group by teaching speaking without any technology interaction (5) Giving post-test after the treatment are completed by both groups, (6) Analyzing post-test result for each group to measure the effect of each treatment, (7) Make a conclusion based on the result of post-test for each group to answer research hypothesis. 
This research is conducted in Universitas Muhammadiyah Malang. It is located in Kampus 3, Jalan tlogomas No. 246 Malang. The researcher chooses this university because English class-called English for Specific Purposes- is compulsory for freshmen from all departments. It has 10 faculties and 45 departments. The subjects of this study are students form electrical engineering department who attend special English class held by Language Center of Universitas Muhammadiyah Malang. There are four class based on four skills of English and two language class beside English, Japanese and Mandarin Chinese. The researcher only chooses Speaking class from this program to conduct the research. From classes-Listening, Reading 2, Speaking 2, Integrated 2, Mandarin and Japan - in ESP 1 program that available in Universitas Muhammadiyah Malang, ESP Speaking 1 course is chosen for this study. This course is chosen because it is accessible to be involved in this study. This course also suitable because students are digital natives and familiarized with mobile phone technology. This study will not disrupt the teaching and learning schedule of ESP 1 program since the implementation time are same. Students in both groupexperimental and control — will be treated for eight meetings.

Students in the experimental group receives mobile phone implementation to their teaching learning activity. The students are required to participate themselves in classroom activity with mobile phone which facilitated with internet connection. They are also required to participate online lectures and activity through mobile phone.

To implementation mobile phone in this study is covering as teaching aid and learning platform. therefore, four apps are chosen as a supporting tool in teaching speaking, YouTube, Instagram, Search engine apps and WhatsApp. YouTube used as teaching aid, where teacher share links of video or present some video in the classroom activity. Instagram used as teaching materials, teacher can share some content to class and have discussion with their students. Search engine apps like Chrome, Opera, Mozilla or Safari are used to help students find individual material or information. WhatsApp used to communicate, sharing teaching materials or media in face-to-face lectures. While in outside classroom, it can be used to store and collect video, audio or voice from students inform of voice note.

Students in the control group receives no technology interaction in their teaching learning activity. Any communication is done in class and face-to-face outside class. Pen and whiteboard are used as teaching media. Students in control group receive materials at classroom meetings. Some materials will be delivered in printed students' material by teacher. The students are required to participate themselves in classroom activity without any technology interaction. They are also can meet the teacher outside classroom if they have questions or need help to do assignment.

This research use scores from speaking test, Pre-test and Post-test. The speaking Pre-test is in form of self-introduction task, here students have to speak about anything related to their university life in front of their friends and researcher. The speaking Post-test is in form of public speaking, here students have to deliver their opinion and idea to the peers and researcher. The students have one day before meeting to prepare outline for their speaking what they going to say. There is no direct feedback from researcher while students do this task. Researcher rate the students speaking performance.

Beside scores from speaking test, online questionnaire about students' perception on the use of mobile phone also included in this study. Questionnaire as its instrument to collect data from the subject. The questionnaire is in the form of online survey to make access easier for the respondents. The online questionnaire is shared via link of Goggle form. Video recorder included in this research to record students' speaking performance in speaking pre- and post-test. Speaking pre-test and post-test is given to both experimental and control group. It administered to collect initial scores which reflect students' speaking performance. Scores from pre-test needed to determines statistical analysis in the post-test.

As mentioned previously, pre-test and post-test will be in the form of public speaking, here students have to deliver their opinion and idea to the peers and researcher. The students have one day before meeting to prepare outline for their speaking performance. There is no direct feedback from researcher while students do this task. In pre-test session, students are instructed to tell their experience for past academic experience in learning English and their goal in speaking class. While in post-test, students are instructed to deliver their opinion about some specific topic in their field.

Scoring rubric needed in this study since its measured students' speaking achievement. According to Thornburry (2005), there are two way to assessing students' speaking ability, holistic scoring and analytic scoring. Holistic scoring is single score for overall performance. This scoring is easier to do since measure speaking performance in broader way and adequate for informal testing. While analytic scoring measure speaking performance in some specific aspects. It takes longer time to do and probably fairer and reliable since measure speaking in different parts. This study measures students' speaking performances in both pre-test and post-test use analytic scoring since it measures quality of each speaking aspects. To reduce subjectivity while scoring students' speaking, researcher employs inter-rating scoring. The researcher collaborates with the classroom teacher to assess students' speaking performance in pre-test and post-test.

Online questionnaire was used to support score from experimental group. about students' perception on the use of mobile phone in language teaching. The questionnaire is in the form of online survey to make access easier for the respondents. The online questionnaire is shared via link of Goggle form. Data on students' perceptions collected using a questionnaire adapted from Dashtestani (2013). Questionnaire is delivered using Bahasa Indonesia to avoid misunderstanding of every item on it. Students required to choose one of the five degrees of likert-Scale: strongly disagree, disagree, neutral, agree, strongly agree. 
Video recorder included in this research to record students' speaking performance in speaking pre- and post-test. The recorder can be played several times by researcher and teacher as the original source to measuring students' speaking performance accurately. Teacher and researcher may need to reassess students' speaking performance by listening to video recorder to give appropriate score for each aspect in scoring rubric.

Data from scores based on students speaking test were gathered and compared between mean score from experiment class and control class at the end of the research. The data were analysis and interpreted to answer the research questions. The score from speaking test was intended to evaluate students' performance before and after the treatment given.

Data analysis aims at analysing score from speaking test to answer research problem and test research hypothesis. Quantitative analysis is conducted by computing score based on empirical data. Score from both groups will be compared after pre-test and post-test to measure the effect of the treatment. This analysis describes mean, maximum score, minimum score, range and standard deviation of students' speaking score. These data are presented in diagram. Next is find the significance differences of students' speaking performance in the experimental and control group using inferential statistics. The analysis is carried out using statistical software, Statistical Package for the Social Sciences or known as SPSS.

There are several statistical tools will be used to analyse score from this study, normality test, levene's test of variance and independent t-test. Detailed explained of statistical tool is presented in the following sections.

Normality test is conducted by using Kolmogorov-smirnov test. It is done to make sure that data obtained from students' pre-test are normally distributed, then continue to parametric statistic. If the data obtained not normally distributed, non-parametric statistic are employed in this study. The p value used in this study is $5 \%$.

Students' initial ability in speaking from both group-control and experimental-will measure by Levene's test before the treatment is given to both groups. Result from this test will determine the statistical tools used in analysing post-test score. Independent t-test will be used if mean score from both groups are not significantly difference.

\section{FINDING}

This section presents the result of the research to reveal the effect of mobile phone as teaching aid on students' speaking performance. The analysis was done in order to find out the students' speaking performance which was taught in a class applying mobile phone. The descriptive data of students' score and the result of hypothesis testing are reported.

The main instrument of this study used to collect initial scores which reflect students' speaking performance was conducted in both groups-Experimental and Control Groups. The speaking pre-test were administered before 8 meeting of treatment. The speaking post-test were administered after 8 meetings of treatment in both groups. The post-test in the experimental group was conducted on December 18th, 2019, while the post-test for control group was conducted day before, December 17th,2019. Time allotment for conducting test for both experimental and control groups was 100 and all students attended the post-test. The result of pre-test and post-test from both groups was analysed using descriptive statistic on SPSS 25 . This is used to describe students' speaking score from both groups. The result is displayed in Table 1

Tabel 1. Descriptive Statistics

\begin{tabular}{lrrrrr}
\hline \multicolumn{7}{c}{ Descriptive Statistics } \\
\hline & N & Minimum & Maximum & Mean & Std. Deviation \\
\hline Pre-Test Experiment Group & 19 & 4.00 & 10.00 & 7.3079 & 2.03867 \\
\hline Post-Test Experiment Group & 19 & 8.55 & 18.80 & 13.5368 & 2.97017 \\
\hline Pre-Test Control Group & 19 & 4.00 & 10.95 & 7.6533 & 1.86539 \\
\hline Post-Test Control Group & 19 & 6.10 & 11.85 & 8.8553 & 1.68440 \\
\hline Valid N (listrisis) & 19 & & & & \\
\hline
\end{tabular}

Based on table 1, the Pre-Test scores from Experimental group ranged from 4.00 to 10.00 with standard deviation (SD) 2.03 while for Control group ranged from 4.00 to 10.95 with standard deviation (SD) 1.86. The mean scores of Pre-test from Experimental group 7.30 and 7.65 for Control group. It was concluded that the mean for both groups are almost similar.

Meanwhile, the Post-Test scores from Experimental group ranged from 8.55 to 18.80 with standard deviation (SD) 2.97 while for Control group ranged from 6.10 to 11.85 with standard deviation (SD) 1.68. The mean scores of Post-test from Experimental group 13.53 and 8.85 for Control group. It was concluded that the mean for experimental group was higher than control group.

The first research problem was addressed on whether students taught using mobile phone have higher speaking performance than those taught without it. To test this hypothesis, parametric statistic used to analyse differences between student' speaking performance in experimental group and control group. Since normality and homogeneity assumptions is fulfilled, parametric statistic employed. Independent Samples Test was selected to analyse this data. The result of the data analysis is shown in table 2 and 3. 
Tabel 2. Pretest Score

\begin{tabular}{llcllrr}
\hline & Group & N & Mean & SD & t-count & Sig. (2-tailed) \\
\hline Pre-Test & Experimental Group & 19 & 7.3079 & 2.03867 & .548 & .587 \\
Score & Control Group & 19 & 7.6553 & 1.86539 & .548 & .587 \\
\hline
\end{tabular}

Tabel 3. Posttest Score

\begin{tabular}{llcccrr}
\hline & Group & N & Mean & SD & t-count & Sig. (2-tailed) \\
\hline Post-Test & Experimental Group & 19 & 13.5368 & 2.97017 & 5.976 & .000 \\
Score & Control Group & 19 & 8.8553 & 1.68440 & 5.976 & .000 \\
\hline
\end{tabular}

From table 2 indicates that significance value is .587 , this significance value is higher than .005. There is no significance different between Experimental and Control group. Therefore, initial score from both group before treatment are mutual. From table 3 indicates that significance value is .000 , this significance value is lower than .05 . Therefore, there are significance different of mean between experimental and control group. In other word it can be concluded that students taught using mobile phone have higher speaking performance than those taught without it. Moreover, summary of Pre-test and Posttest score from both Experimental and Control Groups displayed in table 4.

Tabel 4. Pretest and Posttest Score

\begin{tabular}{lllll}
\hline & Pre-test & & Post-Test & \\
\cline { 2 - 5 } & Experimental & Control & Experimental & Control \\
\hline $\mathbf{N}$ & 19 & 19 & 19 & 19 \\
Minimum & 4.00 & 4.00 & 8.55 & 6.10 \\
Maximum & 10.00 & 10.95 & 18.80 & 11.85 \\
Mean & 7.3079 & 7.6533 & 13.5368 & 8.8553 \\
\hline
\end{tabular}

Based on table 4 displays that the scores from both experimental and control group in post-test was better than score from pre-test. The mean score from pre-test was 7.30 for experimental group and 7.65 for control group. The mean score from post-test was 13.53 for experimental group and 8.85 for control group. Score from experimental group in post-test were better than score in pre-test, 13.53 to 7.30 . There was 6.23 points of mean difference between means of pre-test and post-test in both groups.

Students' perceptions of Mobile Phone in their learning activity were acquired from online questionnaire in form of Google Form and shared via WhatsApp Group. The questionnaire consists of 10 questions and translated into Bahasa Indonesia avoid misunderstanding of every item on it. From 19 students in experimental group, only 17 students fill the questionnaire. Majority of students agreed to questionnaire items.

Based on the result of questionnaire shows that majority of the students agreed with questionnaire items. According to the result, majority of students are agree to some questionnaire items; most of students found no difficulty using mobile phone in their learning (82\%), most students think that teacher should give lesson through mobile phone (71\%), most of students found that learning material which shared via mobile phone makes them easier to learn $(75 \%)$, most of students thinks that learning materials shared via mobile phone is more accessible than conventional materials $(76 \%)$, most of students thinks that learning materials shared via mobile phone facilitate them to be more autonomous (81\%), most of the students thinks that learning materials shared via mobile phone are helping them to understand more in learning English (86\%), most of students thinks that teacher should develop learning material through features on mobile phone (79\%) and most of students thinks that teacher can give direct feedback for my assignment by using features on mobile phone (71\%).

\section{DISCUSSION}

This study examined the effect of using mobile phone in teaching and learning speaking compared to conventional teaching and learning on students' speaking performance. As mentioned in previous chapter, this study revealed that students taught using mobile phone outclassed those students who were taught using conventional media. Post-test Score from both 
Experimental and Control group has significant difference, the experimental group which was taught by using mobile phone in their learning activity has higher score than the control group which was taught using conventional media. The post-test scores of both groups has significance value lower than the p-value $(0.000<0.05)$, it shows that there is statistically significance different of post-test score from both experimental and control group. The mean scores of Post-test from Experimental group 13.53 and 8.85 for Control group. It was concluded that the mean for experimental group was higher than control group between experimental and control group. In another word, using mobile phone in teaching speaking was considered effective in this study.

The comparison of mean score before and after treatment from experimental and control group shows an improvement in their speaking performance. Control group's pre-test mean score was 7.65. After treatment using conventional teaching, their score increased 1.2 to 8.85 in post-test. While experimental group's pre-test mean score was 7.30. After treatment using mobile phone in teaching and learning activity, their score increased 6.23 to 13.53 in post-test. In another word, experimental group' mean score increased more than control group $(1.2<6.23)$. Moreover, it can be concluded that Students who are taught using of mobile phone have higher speaking performance than those who are taught without using mobile phone in the learning activity.

Based on findings of this study show the advantages of using mobile phone in teaching speaking. Beside higher score that experimental groups obtain, students feels more comfortable in learning and practice speaking English. There are several reasons supporting this finding.

Since all of students are digital native (Prensky, 2008), they feel comfortable to learn and practice speaking English with their personal mobile phone. All of learning material in experimental group are delivered through mobile phone, this situation helping student to get learning material easier than conventional method. Besides learning material sent by the teacher in classroom, students also get authentic materials from web search engine, or another application such as Instagram and YouTube. Features on mobile phone such as camera, web search engine and microphone, also some applications such as WhatsApp, Instagram and YouTube have become platform for students and teacher to interact in language classroom (Ngaleka \& Uys, 2013).

Students practice their speaking not only inside classroom, but also outside classroom. Students are having more chance to speak outside the classroom. By giving assignment through voice note or video, student feel free to practice their speaking in anytime and anywhere and had no pressure. This activity encourages students to practice their confidence (Brown and Lee,2015). By using camera and microphone in their mobile phone, students can practice their speaking with their peers and teacher in form of voice note or Video and share it through WhatsApp group.

Practicing speaking in voice note or video makes students less nervous since they do not have to face their peers or teacher. Learning and practicing English through mobile phone helps them reduce their nervous and raised their confidence (Almelkhlafy and Alzubi, 2016). Students were given more time to practice their speaking performance with their mobile phone. Students did not feel stressed while performing their speaking and they can explore their speaking skill, fixing the mispronunciation or articulation they made before recorded it. Moreover, students can maintain their speaking output since they have authority and can retake the audio or video until get the result that they want.

Based on questionnaire result in previous chapter, most of students in experimental groups shows positive perceptions toward mobile phone use in their learning activity. This result are in line with other studies ( Khrisat \& Mahmoud, 2013; Dashti \& Aldhasti, 2015; Brick \& Cervi-Wilson, 2015; Nalliveetil \& Alenazi, 2016; Botero et al., 2018) which revealed positive perceptions from EFL Students toward the use of mobile phone in Learning English. Most of students are agree that using mobile phone are easier to them since most of students are digital natives and get used to using mobile phone.

Mobile phone portability aspects supporting them to use it in anywhere. Accessibility characteristic of learning using Mobile phone shows with teacher accommodate her teaching material shared through mobile phone. This aspect supporting students to access learning material from anywhere and anytime. Thus, students be more autonomous and helping them to understand in learning English. Implementation of mobile phone in their learning activity could ease their learning. Learning resources from Instagram, videos on YouTube and article in web search engine are able to support students in understanding more about learning English and also improving their interaction (Patten \& Craig, 2007)

Feature on mobile phone like microphone and camera helping students to perform their speaking virtually, they can share their speaking performance to WhatsApp Group and get feedback from peers and teacher. By performing their speaking through mobile phone feature, students are able to take number of samples before sending out the best voice notes or videos to the WhatsApp group that showcase their most advanced speaking performance. By this mean, it is expected students will be less nervous while practicing their speaking as they are self-recording their performances.

In conclusion, most of students in Experimental group admitted that implementation of mobile phone in their learning activity is useful, easy to use, fun, and accommodating them to be more autonomous. Learning material shared through mobile phone makes them more accessible than conventional media. Material which come from Instagram, YouTube Videos and article in Web Search Engine bring authentic materials to students, thus students may brainstorm and build their ideas as to fulfil their needs. Students are able to learn and perform their speaking in anywhere and anytime they want. 


\section{CONCLUSIONS}

Based on the result in previous discussion, it is shown that students' speaking performance in experimental group outperformed students in control group. Score from both group are significantly different and show higher score from experimental group. It is significantly prove that mobile phone has positive effect toward students' performance in experimental group. Students in experimental group who got treatment using mobile phone also have positive impact towards mobile phone in learning English.

This study provide theoretical and practical contribution in teaching English, especially in mobile learning. Teaching and learning English, especially speaking skill enriched by this study. This study provide empirical data via its instruments as the data to reveal students' speaking performance in speaking class. The result of this study give a new perspective about the use of mobile phone in classrooms. By learning the impact of mobile phone on EFL speaking performance, teachers are able to reinvent new perspectives on using mobile devices for educational purposes - either positive or negative outcomes. This study can be reference about implementation of mobile phone as teaching aid in speaking class. For future researcher, by using result from this study could developed another study related to mobile phone and other English skill. Adding different variables expected to give broader perspective with different level of education.

\section{REFERENCES}

Alamer, A. (2015). The Role of Efl Learners' Motivation in Mobile Language Learning. First International Conference on Theory and Practice, December, 142-153.

Almekhlafy, S., \& Alzubi, A. (2016). Mobile-Mediated Communication a Tool for Language Exposure in EFL Informal Learning Settings. Arab World English Journal, 7(1), 388-407. https://doi.org/10.24093/awej/vol7no1.23

Andrade, M. de L. (2014). Role of Technology in Supporting English Language Learners in Today's Classrooms. April.

Bouhnik, D., \& Deshen, M. (2014). WhatsApp Goes to School: Mobile Instant Messaging between Teachers and Students. Journal of Information Technology Education: Research, 13, 217-231. https://doi.org/10.28945/2051

Brick, B., \& Cervi-Wilson, T. (2015). Technological diversity: A Case Study into Language Learners' Mobile Technology Use Inside and Outside the Classroom. 10 Years of the LLAS Elearning Symposium: Case Studies in Good Practice, 2015, 2130. https://doi.org/10.14705/rpnet.2015.000264

Broadbent, J. (2017). Comparing Online and Blended Learner's Self-Regulated Learning Strategies and Academic Performance. Internet and Higher Education, 33, 24-32. https://doi.org/10.1016/j.iheduc.2017.01.004

Calvo, R., Arbiol, A., \& Iglesias, A. (2014). Are all Chats suitable for learning purposes? A Study of the Required Characteristics. Procedia Computer Science, 27(Dsai 2013), 251-260. https://doi.org/10.1016/j.procs.2014.02.028

Dashtestani, R. (2013). Implementing Mobile-Assisted Language Learning (MALL) in an EFL Context: Iranian EFL Teachers' Perspectives on Challenges and Affordances. JALT CALL Journal, 9(2), 149-168.

García Botero, G., Questier, F., \& Zhu, C. (2019). Self-Directed Language Learning in a Mobile-Assisted, Out-of-Class Context: Do Students Walk The Talk? Computer Assisted Language Learning, 32(1-2), 71-97. https://doi.org/10.1080/09588221.2018.1485707

Gikas, J., \& Grant, M. M. (2013). Mobile Computing Devices in Higher Education: Student Perspectives on Learning with Cellphones, Smartphones \& Social Media. Internet and Higher Education, 19, 18-26. https://doi.org/10.1016/j.iheduc.2013.06.002

Khrisat, A. A., \& Mahmoud, S. S. (2013). Integrating Mobile Phones into the EFL Foundation Year Classroom in King Abdulaziz University/KSA: Effects on Achievement in General English and Students' Attitudes. English Language Teaching, 6(8), 162-174. https://doi.org/10.5539/elt.v6n8p162

Kim, H., \& Kwon, Y. (2012). Exploring Smartphone Applications for Effective Mobile-Assisted Language Learning. Multimedia-Assisted Language Learning, 15(1), 31-57.

Kukulska-Hulme, A., \& Shield, L. (2008). An Overview of Mobile Assisted Language Learning: From Content Delivery to Supported Collaboration and Interaction. ReCALL, 20(3), 271-289. https://doi.org/10.1017/S0958344008000335

Nalliveettil, G. M., \& Alenazi, T. H. K. (2016). The Impact of Mobile Phones on English Language Learning: Perceptions of EFL Undergraduates. Journal of Language Teaching and Research, 7(2), 264. https://doi.org/10.17507/jltr.0702.04

Ngaleka, A., \& Uys, W. (2013). M-Learning with WhatsApp: A Conversation Analysis. Proceedings of the International Conference on E-Learning, ICEL, July, 282-291.

Ok, M. W., \& Ratliffe, K. T. (2018). Use of Mobile Devices for English Language Learner Students in the United States: A Research Synthesis. Journal of Educational Computing Research, 56(4), 538-562. https://doi.org/10.1177/0735633117715748

Patten, Kathryn B., Craig, Valcarcel, D. (2007). iPods and English-Language Learners: A Great Combination. Teacher Librarian, 34(5), 40-44.

Prensky, M. (2001). Digital Natives, Digital Immigrant. On the Horizon (MCB University Press), Vol 9(5). https://www.marcprensky.com/writing/Prensky - Digital Natives, Digital Immigrants - Part1.pdf 
Raiman, L., Antbring, R., \& Mahmood, A. (2017). WhatsApp Messenger as a Tool to Supplement Medical Education for Medical Students on Clinical Attachment. BMC Medical Education, 17(1), 1-9. https://doi.org/10.1186/s12909-0170855-x

Samaie, M., Mansouri Nejad, A., \& Qaracholloo, M. (2018). An Inquiry into the Efficiency of WhatsApp for Self- and PeerAssessments of Oral Language Proficiency. British Journal of Educational Technology, 49(1), 111-126. https://doi.org/10.1111/bjet.12519

Song, Y., \& Siu, C. K. (2017). Affordances and Constraints of BYOD (Bring Your Own Device) for Learning and Teaching in Higher Education: Teachers' Perspectives. Internet and Higher Education, 32, 39-46. https://doi.org/10.1016/j.iheduc.2016.08.004 